\title{
Migotanie przedsionków w zaciskającym zapaleniu osierdzia
}

\author{
Atrial fibrillation in patient with constrictive pericarditis
}

\author{
Agnieszka Langiewicz, Grzegorz Skonieczny \\ Oddział Kardiologii i Intensywnego Nadzoru Kardiologicznego Wojewódzkiego Szpitala Zespolonego \\ im. Ludwika Rydygiera w Toruniu \\ Oddział Intensywnej Terapii Kardiologicznej Wojewódzkiego Szpitala Zespolonego im. Ludwika Rydygiera w Toruniu
}

\section{Streszczenie}

Migotanie przedsionków (AF), występujące u 1-2\% populacji ogólnej, to najczęstsze utrwalone zaburzenie rytmu serca. Ze względu na możliwe powikłania zakrzepowo-zatorowe pacjenci z AF oraz obarczeni czynnikami ryzyka wymagają leczenia przeciwkrzepliwego. Według raportu Światowej Organizacji Zdrowia tylko 50\% pacjentów stosuje się do zaleceń lekarskich. W wielu badaniach podkreśla się, że zrozumienie przez chorego sensu działań diagnostycznych i leczniczych sprzyja ich akceptacji i zasadniczo poprawia efektywność terapii. Migotanie przedsionków często występuje u osób z zaciskającym zapaleniem osierdzia, szczególnie jeśli okres trwania choroby jest dłuższy.

Słowa kluczowe: migotanie przedsionków, zaciskające zapalenie osierdzia

Folia Cardiologica 2017; 12, 1: 81-85

\section{Opis przypadku}

Chora w wieku 61 lat zgłosiła się na szpitalny oddział ratunkowy (SOR) z powodu narastającego od 2 tygodni pogorszenia tolerancji wysiłku oraz duszności wysiłkowej i uczucia kołatania serca. W wywiadzie chorobowym ustalono, że pacjentka w dzieciństwie przebyła zapalenie mięśnia sercowego. Poza tym negowała choroby przewlekłe i przyjmowanie leków na stałe. Podała, że pali papierosy - około 10/dobę. W badaniu przedmiotowym stan ogólny okazał się średnio dobry; czynność serca była niemiarowa i wynosiła $120 /$ min, nad polami płucnymi stwierdzono prawidłowy szmer pęcherzykowy, ściszony u podstawy płuca prawego, a ponadto wodobrzusze umiarkowanego stopnia i nasilone obrzęki kończyn dolnych.

Wyniki badań laboratoryjnych były następujące: liczba leukocytów 9,97 G/L, liczba erytrocytów 4,57 T/L, stężenie hemoglobiny 12,9 d/dl, liczba płytek krwi $154 \mathrm{G} / \mathrm{L}$, stężenie białka C-reaktywnego (CRP, C-reactive protein) 3,9 mg/l, aktywność aminotransferazy alaninowej (AIAT, alanine aminotransferase) 20 j./l, aktywność aminotransferazy asparaginianowej (AspAT, aspartate aminotransferase) $35 \mathrm{U} / \mathrm{l}$, aktywności gammaglutamylotranspeptydazy (GGTP, gamma-glutamyl transpeptidase) $313 \mathrm{j}$./l, stężenie bilirubiny całkowitej 2,17 mg/dl, wartość międzynarodowego współczynnika znormalizowanego (INR, international normalized ratio) czasu protrombinowego 1,54, stężenie kreatyniny w surowicy 0,47 mg/dl, wartość współczynnika przesączania kłębuszkowego (GFR, glomerular filtration rate) 106,61 ml/ /min/1,73 $\mathrm{m}^{2}$. W badaniu elektrokardiograficznym (EKG) stwierdzono migotanie przedsionków (AF, atrial fibrillation) z szybką czynnością komór wynoszącą 150/min oraz zmienną amplitudę zespołów QRS (ryc. 1). Z kolei w badaniu radiologicznym klatki piersiowej uwidoczniono płyn w prawej jamie opłucnowej do wysokości VIII żebra w środkowej linii pachowej, natomiast w rzucie sylwetki serca w polu dolnym lewego płuca - dobrze wysycone cienie do $15 \mathrm{~mm}$, najprawdopodobniej zwapnienia (ryc. 2).

Pacjentkę przyjęto na oddział kardiologii, gdzie wdrożono intensywne leczenie, uzyskując poprawę stanu klinicznego,

Adres do korespondencji: lek. Agnieszka Langiewicz, Oddział Kardiologii i Intensywnego Nadzoru Kardiologicznego, Wojewódzki Szpital Zespolony im. Ludwika Rydygiera, św. Józefa 53/59, 87-100 Toruń, e-mail: a.langiewicz@onet.pl 

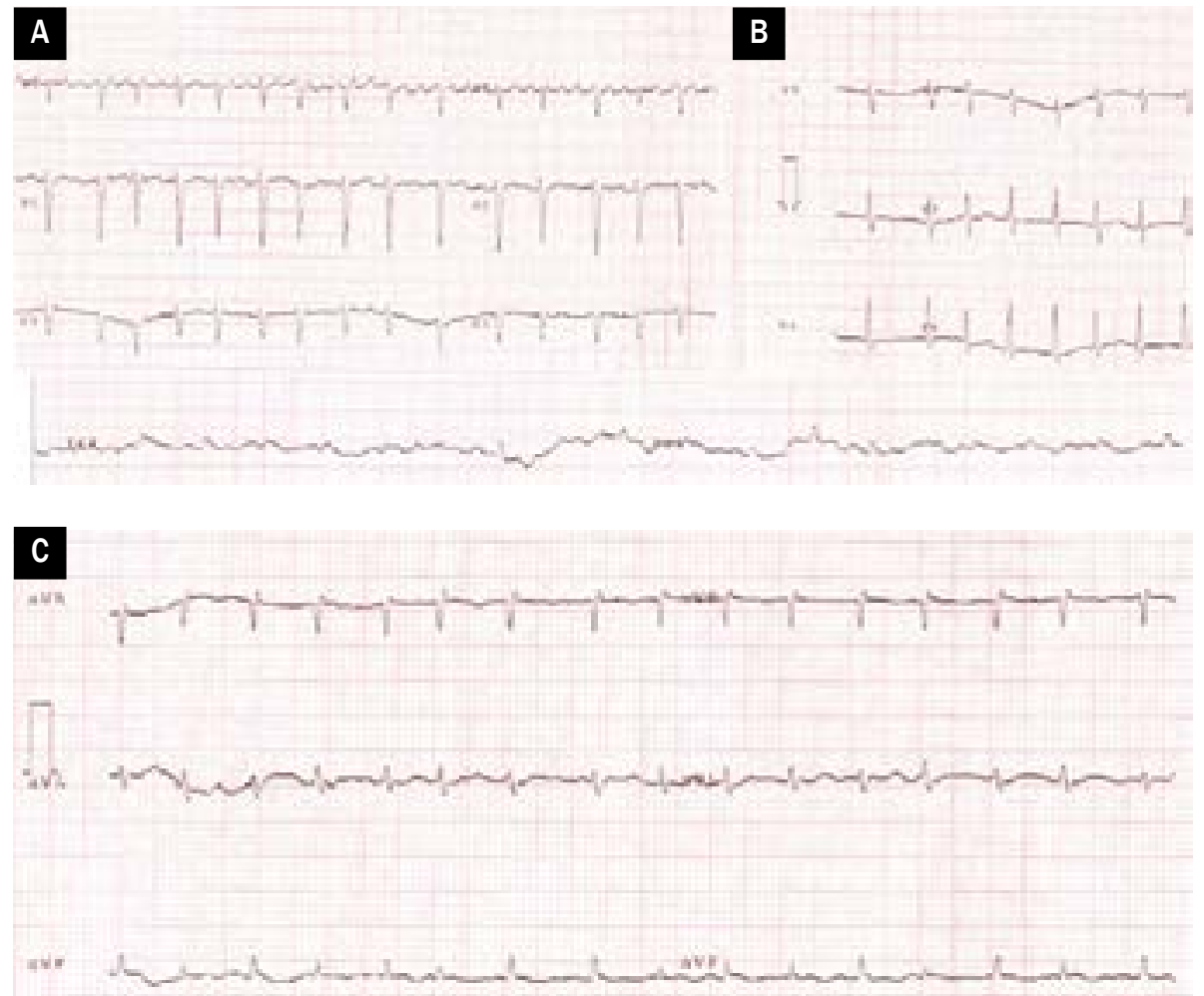

Rycina 1A-C. Zapis elektrokardiograficzny u opisanej chorej

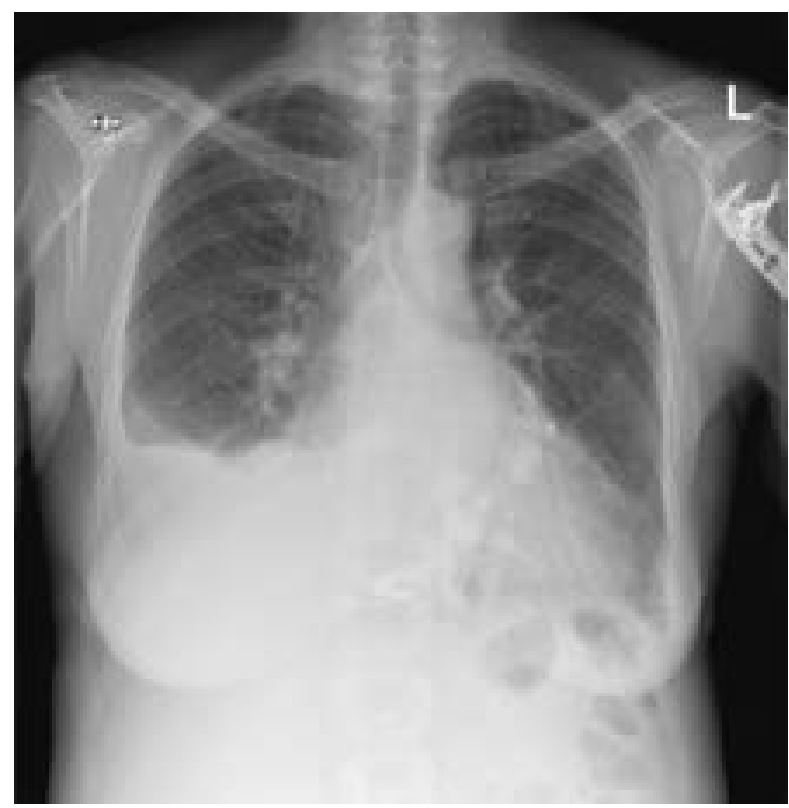

Rycina 2. Badanie radiologiczne klatki piersiowej przy przyjęciu

ograniczenie wodobrzusza i obrzęków kończyn dolnych, a także znaczne zmniejszenie masy ciała - z 66 do $52 \mathrm{~kg}$. $Z$ powodu stwierdzonego AF o nieustalonym czasie trwania oraz wysokiego ryzyka powikłań zakrzepowo-zatorowych 2 punkty w skali $\mathrm{CHA}_{2} \mathrm{DS}_{2}$-VASc (niewydolność serca, płeć;
Tabela 1. Skala oceny ryzyka udaru niedokrwiennego mózgu u chorych z migotaniem przedsionków niezwiązanym z wadą zastawkową $\left(\mathrm{CHA}_{2} \mathrm{DS}_{2}\right.$-VASc) (źródło [1])

\begin{tabular}{llc} 
& Czynniki ryzyka & Punktacja \\
C & $\begin{array}{l}\text { Zastoinowa niewydolność serca lub } \\
\text { dysfunkcja lewej komory }\end{array}$ & 1 \\
H & Nadciśnienie tętnicze & 1 \\
A & Wiek $\geq 75$ lat & 2 \\
D & Cukrzyca & 1 \\
S & Przebyty udar mózgu lub TIA, lub inny & 2 \\
V & incydent zakrzepowo-zatorowy & \\
A & Choroba naczyniowa & 1 \\
Sc & Wiek 65-74 lat & 1 \\
\hline
\end{tabular}

tab. 1) - włączono leczenie przeciwkrzepliwe heparyną drobnocząsteczkową w dawce 60 mg stosowaną 2 razy/ /dobę podskórnie. Na podstawie wywiadu chorą zakwalifikowano do grupy niskiego ryzyka krwawienia - 1 punkt w skali HAS-BLED (nieprawidłowa funkcja wątroby) (tab. 2).

Podczas pobytu chorej na oddziale wykonano u niej badanie echokardiograficzne, w którym stwierdzono powiększenie obu przedsionków, umiarkowanie upośledzoną funkcję skurczową prawej i lewej komory z frakcją wyrzu- 
Tabela 2. Skala HAS-BLED do oceny ryzyka krwawienia u chorych z migotaniem przedsionków (źródło [1])

$\begin{array}{clc} & \text { Czynniki ryzyka } & \text { Punktacja } \\ \text { H } & \text { Nadciśnienie tętnicze }^{1} & 1 \\ \text { A } & {\text { Nieprawidłowa czynność } \text { nerek }^{2}}^{\text {lub wątroby }}{ }^{3} & \text { 1 lub 2 } \\ & \text { Udar mózgu } & \\ \text { B } & \text { Krwawienie }^{4} & 2 \\ \text { L } & \text { Niestabilne wartości INR }^{5} & 1 \\ \text { E } & \text { Starszy wiek > 65 lat }_{\text {D }} & \text { Leki }^{6} \text { lub alkohol }\end{array}$

${ }^{1}$ Skurczowe ciśnienie tętnicze > $160 \mathrm{~mm} \mathrm{Hg} ;{ }^{2}$ przewlekła dializoterapia, stan po przeszczepieniu nerki lub stężenie kreatyniny w surowicy $>200 \mu \mathrm{mol} / \mathrm{l} ;{ }^{3}$ przewlekła choroba wątroby (np. marskość) lub cechy biochemiczne istotnego uszkodzenia wątroby (np. wartość bilirubiny $>2 \times$ ULN + AlAT/AspAT/fosfataza zasadowa $>3 \times U L N):{ }^{4}$ krwawienie w wywiadzie i/lub predyspozycja do krwawin (np.

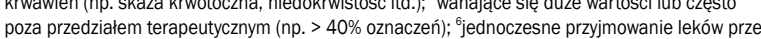
ciwpłytkowych lub niesteroidowych leków przeciwzapalnych; INR (international normalized ratio) - międzynarodowy współczynnik znormalizowany; ULN (upper limit of normal) - górna granica normy; AlAT (alanine aminotransferase) - aminotransferaza alaninowa; AspAT (aspartate aminotransferase) - aminotransferaza asparaginianowa

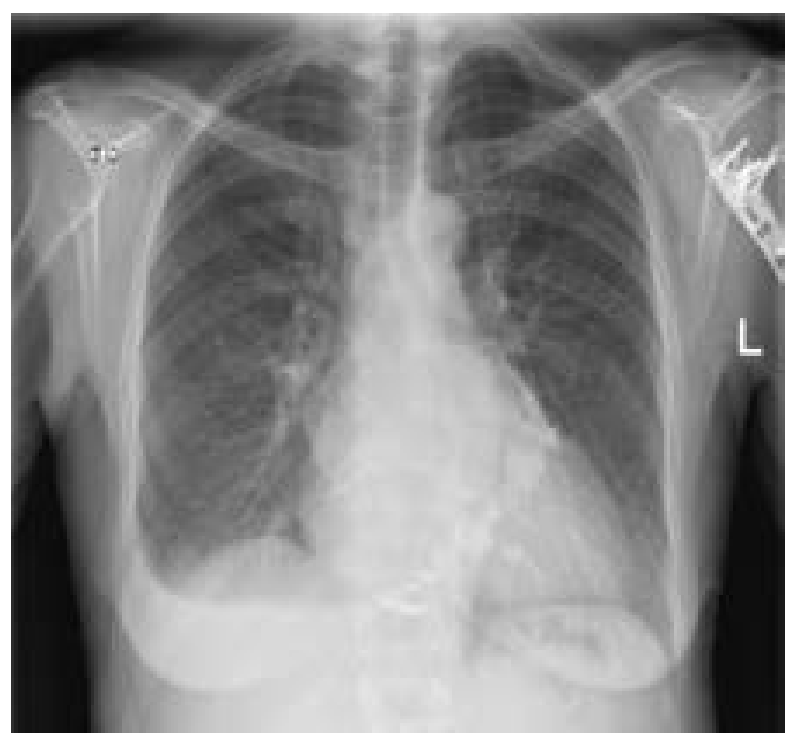

Rycina 3. Badanie radiologiczne klatki piersiowej po leczeniu

tową (EF, ejection fraction) wynoszącą $45 \%$ oraz cechy sugerujące umiarkowane nadciśnienie płucne (ryc. 3).

Wyniki badań laboratoryjnych wykonanych w tracie pobytu w oddziale były następujące: stężenie N-końcowego fragmentu propeptydu natriuretycznego typu $B$ (NT-proBNP, N-terminal B-type natriuretic propeptide) 2516 pg/ml, aktywności GGTP 397 j./l, stężenie bilirubiny całkowitej 1,36 mg/dl, wartość INR 1,3, stężenie kreatyniny w surowicy 0,71 mg/dl, wartość GFR 91,92 ml/ /min/1,73 $\mathrm{m}^{2}$, stężenie albumin 4,0 g/dl. W kontrolnym badaniu radiologicznym klatki piersiowej stwierdzono

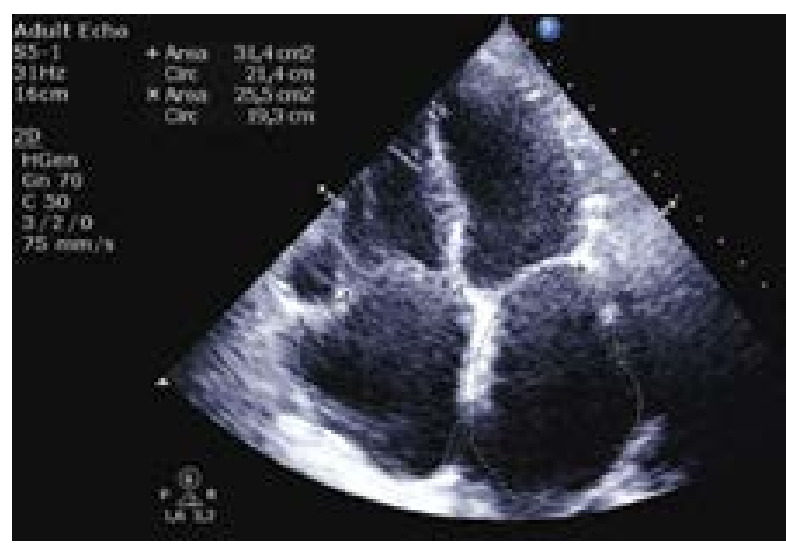

Rycina 4. Badanie echokardiograficzne w projekcji koniuszkowej czterojamowej

zmniejszenie ilości płynu w prawej jamie opłucnowej (ryc. 4).

Po 9 dobach pobytu na oddziale chorą w stanie poprawy wypisano do domu z zaleceniem dalszej opieki w poradni lekarza rodzinnego oraz systematycznego przyjmowania leków: furosemidu, ramiprilu, digoksyny, karwedilolu, spironolaktonu, omeprazolu i chlorku potasu. Ze względu na utrzymujące się wskaźniki uszkodzenia wątroby początkowo nie włączono doustnych leków przeciwkrzepliwych, utrzymując stosowanie heparyny drobnocząsteczkowej w dawce 60 mg, 2 razy/dobę podskórnie. Następnie schemat leczenia przeciwkrzepliwego zmieniono na doustny, włączając riwaroksaban w dawce $20 \mathrm{mg}$ co $24 \mathrm{~h}$. Na podstawie oceny klinicznej i badań dodatkowych wysunięto podejrzenie zaciskającego zapalenia osierdzia i skierowano pacjentkę na dalszą diagnostykę w warunkach ambulatoryjnych.

Po 3 tygodniach chora zgłosiła się na wizytę do przyszpitalnej poradni kardiologicznej. W tym czasie nie skontaktowała się ze swoim lekarzem rodzinnym, leki przyjmowała nieregularnie, tłumacząc to swoim dobrym samopoczuciem. Nie stosowała również leczenia przeciwkrzepliwego. Pacjentkę pouczono o konieczności regularnego stosowania leków. Obecnie pozostaje pod stałą i systematyczną kontrolą poradni kardiologicznej. Jest w trakcie kwalifikacji do ewentualnego zabiegu kardiochirurgicznego.

\section{Omówienie}

Lekarz odbywający dyżury na SOR spotyka się z AF niemal codziennie. W wytycznych European Society of Cardiology (ESC) dotyczących postępowania w AF na 2012 rok ocenia się, że arytmia ta występuje u 1,5-2\% populacji ogólnej i dotyczy głównie osób w wieku 75-85 lat. Migotanie przedsionków zwiększa 5-krotnie ryzyko udaru mózgu i 3-krotnie ryzyko zastoinowej niewydolności serca. Wykrycie arytmii często jest przypadkowe. Pacjenci, którzy trafiają na SOR, 
bardzo często oprócz zwolnienia czynności komór wymagają także włączenia leczenia przeciwkrzepliwego. Do oceny ryzyka wystąpienia powikłań zakrzepowo-zatorowych u chorych z AF służy skala $\mathrm{CHA}_{2} \mathrm{DS}_{2}$-VASc (tab. 1). Obejmuje ona najczęstsze czynniki ryzyka udaru spotykane w codziennej praktyce klinicznej. U pacjentów z wynikiem równym 1 lub wyższym (ale niewynikającym tylko z płci żeńskiej) zaleca się stosowanie doustnych antykoagulantów. U wszystkich pacjentów z AF zaleca się także ocenę ryzyka powikłań krwotocznych, natomiast u chorych z wynikiem równym 3 lub wyższym w skali HAS-BLED (tab. 2) należy zachować ostrożność, systematyczne powtarzać ocenę oraz postarać się o skorygowanie potencjalnie odwracalnych czynników ryzyka krwawienia [1].

Pacjent leczony przeciwkrzepliwie wymaga stałej kontroli w poradni lekarza rodzinnego. Niestety, jak się okazało również w przypadku opisanej pacjentki, większość chorych nie przestrzega zaleceń lekarskich. W ocenie przeprowadzonej przez Światową Organizację Zdrowia (WHO, World Health Organization) w krajach rozwiniętych zaledwie około 50\% pacjentów chorujących przewlekle stosuje się do zaleconego leczenia. Przyczyny tego zjawiska są różne; wśród najważniejszych czynników wymienia się złożoność terapii, czynniki ekonomiczne i brak przekonania chorych o konieczności leczenia, w szczególności w przypadku braku objawów klinicznych. Dlatego u pacjentów leczonych przeciwkrzepliwie bardzo ważne jest zrozumienie przez chorego sensu działań diagnostycznych i leczniczych, co sprzyja ich akceptacji i zasadniczo poprawia efektywność terapii. W praktyce klinicznej taką relację pacjent-lekarz oparto na świadomej i partnerskiej współpracy określanej mianem adherence (z ang. 'trzymanie się planu terapeutycznego') [2]. Systematyczne przyjmowanie leków przez opisaną pacjentkę nie tylko obniży ryzyko powikłań zakrzepowo-zatorowych, ale także ograniczy objawy niewydolności serca. Jednakże w przypadku zaciskającego zapalenia osierdzia farmakoterapia ma charakter wyłącznie wspomagający, a za standardową metodę leczenia uznaje się zabieg chirurgiczny.

Leczenie zachowawcze jest uzasadnione w trzech przypadkach. Po pierwsze, gdy występuje zapalenie osierdzia o szczególnej etiologii, na przykład gruźlicy, to farmakoterapia pozwala zapobiec progresji zapalenia przewlekłego do zaciskającego. Po drugie, gdy zmiany zaciskające w obrębie osierdzia mogą być spowodowane toczącym się procesem zapalnym i mogą mieć charakter potencjalnie odwracalny, to uzasadnione jest stosowanie leków przeciwzapalnych. Po trzecie, gdy istnieją przeciwwskazania do zabiegu operacyjnego, celem farmakoterapii pozostaje złagodzenie objawów zastoinowej niewydolności serca [3].

Zaciskające zapalenie osierdzia to rzadkie schorzenie. W krajach wysoko rozwiniętych ma ono najczęściej charakter idiopatyczny lub rozwija się po zakażeniu wirusowym. Objawy, które zgłaszają chorzy, wynikają z niewydolności prawej komory, i są to: obniżenie tolerancji wysiłku, duszność, obrzęki kończyn dolnych, powiększenie obwodu brzucha. W przypadku dużego stopnia zaawansowania procesu chorobowego dochodzi do upośledzenia funkcji wątroby, powstawania przesięku w jamach opłucnowych oraz do pogrubienia blaszek osierdzia i tworzenia się zwapnień. Za metodę leczenia z wyboru uznaje się perikardiektomię - zabieg chirurgicznego usunięcia worka osierdziowego [3].

Migotanie przedsionków u pacjentów z zaciskającym zapaleniem osierdzia jest częstym zaburzeniem. W badaniu przeprowadzonym przez Rezaiana i wsp. [4] wykazano, że arytmia częściej występuje u chorych ze stwierdzonymi zwapnieniami w osierdziu i dłużej trwającą chorobą. Według wytycznych ESC dotyczących rozpoznawania i leczenia chorób osierdzia z 2015 roku AF może wskazywać na krańcowe stadium choroby, podobnie jak wyniszczenie, mała pojemność minutowa serca w spoczynku, hipoalbuminemia spowodowana enteropatią wysiękową i/lub zaburzenie czynności wątroby ze względu na jej przewlekłe przekrwienie lub marskość kardiogenną [3].

W opisywanym przypadku, z obawy przed pogorszeniem wydolności wątroby, początkowo nie włączono doustnych leków przeciwkrzepliwych. W pracy Witkowskiego i wsp. [5] wśród przeciwwskazań bezwzględnych do stosowania nowych doustnych leków przeciwzakrzepowych (NOAC, new oral anticoagulants) wymienia się choroby wątroby z koagulopatią i niewydolność wątroby B lub C według skali Childa-Pugha (tab. 3 [6]). W tej skali opisana pacjentka jest

Tabela 3. Skala Childa-Pugha (źródło [6])

\begin{tabular}{lccc} 
Oceniany parametr & & Punktacja & 3 pkt. \\
\hline Bilirubina $[\mathrm{mg} / \mathrm{dl}]$ & 1 pkt & 2 pkt. & $>3$ \\
Albumina $[\mathrm{g} / \mathrm{dl}]$ & $<2$ & $2-3$ & $<2,8$ \\
INR & $>3,5$ & $2,8-3,5$ & $>2,20$ \\
Wodobrzusze & $<1,70$ & $1,70-2,20$ & Napięte \\
Encefalopatia wątrobowa & Brak & Umiarkowane & Stopień 3.-5.
\end{tabular}

INR (international normalized ratio) - międzynarodowy współczynnik znormalizowany 
w klasie A niewydolności wątroby z liczbą punktów 6, co oznacza brak przeciwwskazań do włączenia NOAC.

\section{Podsumowanie}

Migotanie przedsionków jest jednym z częstszych zaburzeń rytmu serca spotykanych w codziennej praktyce klinicznej. Leczenie pacjentów z tą arytmią polega nie tylko na kontroli częstotliwości rytmu komór, ale także na prowadzeniu leczenia przeciwkrzepliwego, jeśli istnieją ku temu przesłanki. Czynniki ryzyka powikłań zakrzepowo-zatorowych, według wytycznych ESC dotyczących postępowania w AF z 2012 roku, określa się na podstawie skali $\mathrm{CHA}_{2} \mathrm{DS}_{2}$-VASc. Przy włączaniu takiego leczenia trzeba także wziąć pod uwage przeciwwskazania i sytuacje, w których istnieje zwiększone ryzyko krwawienia określane w skali HAS-BLED. Pacjenci leczeni przeciwkrzepliwie wymagają systematycznej kontroli w poradni lekarza rodzinnego, szczególnie jeśli są obciążeni przewlekłymi schorzeniami.

\section{Konflikt interesów}

Autorzy nie zgłaszają konfliktu interesów związanych z tym artykułem.

\section{Abstract}

Atrial fibrillation is the most common chronic arrhythmia, affecting 1-2\% of general population. Because of the risk of stroke and thromboembolism, patients with atrial fibrillation need anticoagulation. The World Health Organization estimates that only $50 \%$ of patients follow doctors' recommendations. In many researches it is emphasized that understanding the sense of treatment fosters patients' acceptation and enhances the effectiveness of therapy. Atrial fibrillation is common in patients with constrictive pericarditis, especially when the disease is long-standing.

Key words: atrial fibrillation, constrictive pericarditis

Folia Cardiologica 2017; 12, 1: 81-85

\section{Piśmiennictwo}

1. Camm AJ, Lip GY, De Caterina RH, et al. Wytyczne European Society of Cardiology dotyczące postępowania w migotaniu przedsionków na 2012 rok. Kardiol Pol. 2012; 70(suppl. IV): 197-234.

2. Kubica A, Grzesk G, Sinkiewicz W, et al. Compliance, concordance, adherence w przewlekłej terapii. Folia Cardiol Excerpta. 2010; 5(2): 54-57.

3. Adler Y, Charron P, Imazio M, et al. [2015 ESC Guidelines for the diagnosis and management of pericardial diseases]. [Article in Polish]. Kardiol Pol. 2015; 73(11): 1028-1091, doi: 10.5603/KP.2015.0228, indexed in Pubmed: 26726821.
4. Rezaian GR, Poor-Moghaddas M, Kojuri J, et al. Atrial fibrillation in patients with constrictive pericarditis: the significance of pericardial calcification. Ann Noninvasive Electrocardiol. 2009; 14(3): 258-261, doi: 10.1111/j.1542-474X.2009.00307.x, indexed in Pubmed: 19614637.

5. Witkowski M, Witkowska M, Smolewski P. [The latest recommendations on the use of new oral anticoagulants in routine practice]. [Article in Polish]. Postepy Hig Med Dośw (Online). 2016; 70: 43-55, doi: 10.5604/17322693.1194114, indexed in Pubmed: 26864063.

6. Gajewski P. Interna Szczeklika. Podręcznik chorób wewnętrznych 2016. $8^{\text {th }}$ ed. Medycyna Praktyczna, Kraków 2016. 